\title{
Management of acute peripheral arterial injury by using doppler ultrasonography
}

\section{Chapagain, ${ }^{1}$ DJ Reddy, ${ }^{2}$ SK Chadha, ${ }^{2}$ S Agarwal, ${ }^{2}$ KG Shrestha, ${ }^{3}$ S Shah ${ }^{3}$}

${ }^{1}$ M.ch. $3^{\text {rd }}$ year Resident, ${ }^{2}$ Professor CMS-Teaching Hospital, ${ }^{2}$ Professor Sir Gangaram Hospital,New Delhi, ${ }^{3} \mathrm{M}$.ch. residents College of Medical Sciences Teaching Hospital, Bharatpur, Chitwan

\section{ABSTRACT}

\section{Objective}

To determine the effectiveness of the duplex ultrasonography scanning in the management acute peripheral arterial injury.

\section{Materials and methods}

Its a prospective evaluation comparing duplex scanning with operative exploration finding in 78 patients.Duplex scan was used alone for 98 patients having clinical finding of acute vascular insufficiency.

\section{Results}

Duplex scanning had $100 \%$ sensitivity and $95.23 \%$ specificity compared with operative exploration in the 78 cases. Duplex scanning detected 78 injuries, 77 of which were confirmed by correlation with operative exploration and 20 patients did not have vascular injury. One false-positive result was due to spasm of the superficial femoral artery.

\section{Conclusions}

Duplex scanning is a noninvasive, safe, effective, rapid and lesion localising method of initial evaluation for acute peripheral vascular injury having clinical features of vascular insufficiency.

\section{Key words: darterial injury, duplex scan, operative exploration.}

\section{Introduction}

Most extremity injuries are localized to a specific region and occur in patients with an otherwise normal vessel. Arteriographic assessment of an injured limb gives a

Correspondence: Dr. D Chapagain

E-mail-doc_chapagain@yahoo.com global overview of only the arterial system of an entire extremity. Though contrast arteriography has served as the historical 'gold standard' for diagnosis of arterial disease, recent improvements in noninvasive diagnostic methods have made it possible to plan surgical 
D Chapagain et al. Management of acute peripheral arterial injury by using doppler ultrasonography.

treatment without subjecting patients to this invasive procedure. The complications associated with arteriography include allergic reactions, renal failure, puncture site problems, stroke and death. Radiographic contrast media cause severe anaphylactic reactions in less than $2 \%$ of cases. ${ }^{1}$ Duplex scanning provides real time focused assessment of blood flow velocities and waveform characteristics of both arterial and venous abnormality in acute trauma which allows the vascular surgeon making decisions regarding operation when no other diagnostic methods are available. The diagnosis of vascular trauma has increased steadily since routine repair of vascular injuries was initiated during the Korean war. During this war period there was a high incidence of associated injuries and therefore routine exploration of all penetrating wounds in proximity to a neurovascular bundle was the norm. ${ }^{2}$ Improvements in the accuracy of non-invasive testing, together with a mandate to reduce the cost, unwanted complication and limited time, have prompted many vascular surgeons to consider performing vascular surgical procedures based on the results of non-invasive duplex scan alone.

\section{Meterials and Methods}

This prospective study was done between jan2010 to sep 2011. All the traumatic cases with clinical findings suggesting of acute arterial insufficiency like pulselessness, pallor, paresthesia, pain, paralysis, peripheral cooling, arterial bleeding, rapidly expanding hematoma, cyanosis and poor capillary refill having history of trauma within eight hours of incident or whose duplex has already been done showing trauma to major vessels were directly taken to the operation theatre.
In the theatre vascular surgeon used the portable ultrasound Doppler of 3-5 MHz linear probe covered by sterile plastic cover, performed the duplex scan and findings like luminal narrowing, widening, defect, or occlusion of major vessels were recorded. Other Doppler findings like accelerated or blunted peak velocity, spectral broadening were also recorded. Operative findings and the procedure done were recorded. Other injury like fractured bone, joint disruption, muscle injury were also recorded. Immediate postoperative flow was checked by vascular surgeon by Doppler ultrasound. Mode of injury was recorded. Patients with multiple trauma were excluded until other life-threatening injuries were treated. Operative findings were compared with Doppler finding. Post procedure limb viability and the complication releated with post perfusion were recorded. Statistical analysis were done by student $\mathrm{t}$ test, $\mathrm{z}$ test and other appropriate test.

\section{Results}

Using sterile plastic ultrasound probe cover, duplex scans on all patients in this study were of satisfactory quality to allow determination of the presence or absence of vascular injury.There were 98 patients of trauma to periphery having features of peripheral insufficiency had undergone duplex ultrasonography. Seventy eight patients (79.5\%) had extremities injuries like arterial occlusion, intimal flap, incomplete transsection and complete transsection. Sixty (61.2\%) cases of lower limb vessels were involved. Out of this mostly popliteal artery injury of 32(32.6\% ) cases followed by 22(22.4\%) cases of superficial femoris/ profonda femoris artery injuries were observed. 
Journal of College of Medical Sciences-Nepal, 2012, Vol-8, No-3

Table 1: Major vessels involvement by Doppler ultrasound.

\begin{tabular}{|c|c|c|c|c|c|c|}
\hline $\begin{array}{l}\text { Peripheral } \\
\text { region }\end{array}$ & $\begin{array}{l}\text { Major arterial } \\
\text { segment }\end{array}$ & $\begin{array}{c}\text { Number of } \\
\text { arterial } \\
\text { injury }\end{array}$ & Cases & $\begin{array}{l}\text { Normal } \\
\text { finding }\end{array}$ & $\begin{array}{c}\text { Missed } \\
\text { injury }\end{array}$ & $\begin{array}{c}\text { Total } \\
\text { patient }\end{array}$ \\
\hline \multirow{4}{*}{$\begin{array}{l}\text { Upper } \\
\text { limb }\end{array}$} & Subclavian & $1(1 \%)$ & & & & \\
\hline & Axillary & $3(3 \%)$ & & & & \\
\hline & Branchial & $9(9.1 \%)$ & 18 & & & \\
\hline & Radial/Ulnar & $5(5.1 \%)$ & $(18.3 \%)$ & & & \\
\hline \multirow{5}{*}{$\begin{array}{l}\text { Lower } \\
\text { limb }\end{array}$} & Common femoral & $3(3 \%)$ & & & & \\
\hline & Superficial & $22(22.4 \%)$ & & 20 & $\operatorname{Nil}(0)$ & 98 \\
\hline & femoris & $32(32.6 \%)$ & 60 & & & \\
\hline & $\begin{array}{l}\text { Popliteal } \\
\text { Tibial }\end{array}$ & $3(3 \%)$ & $(61.2 \%)$ & & & \\
\hline & Total & $\begin{array}{c}78 \\
(79.5 \%)\end{array}$ & $\begin{array}{c}78 \\
(79.5 \%)\end{array}$ & & & \\
\hline
\end{tabular}

Table 2: Type of pathology by exploration.

\begin{tabular}{lcccccc}
\hline \multicolumn{1}{c}{ Pathology } & $\begin{array}{c}\text { Number } \\
\text { of cases }\end{array}$ & $\begin{array}{c}\text { Number of } \\
\text { positive } \\
\text { exploration }\end{array}$ & $\begin{array}{c}\text { Number of } \\
\text { negative } \\
\text { exploration }\end{array}$ & $\begin{array}{c}\text { Number of } \\
\text { total } \\
\text { exploration }\end{array}$ & $\begin{array}{c}\text { No } \\
\text { exploration }\end{array}$ & $\begin{array}{c}\text { Total } \\
\text { patients }\end{array}$ \\
\hline Intimal injury & $46(55.2 \%)$ & & & & & \\
$\begin{array}{l}\text { Complete } \\
\text { transsection }\end{array}$ & $16(19.2 \%)$ & $77(92.4 \%)$ & $1(1.2 \%)$ & 78 & 20 & 98 \\
$\begin{array}{l}\text { Incomplete } \\
\text { transsection }\end{array}$ & $15(18 \%)$ & & & & & \\
\hline
\end{tabular}

Surgical exploration of 78 patients were performed for correlation. One(1.2\%) patient had false positive scan. There was no evidence of missed vascular injury. There were no false-negative duplex scans. Duplex scanning had a sensitivity of $100 \%$, a specificity of $97.3 \%$, and an overall accuracy of $98.71 \%$ compared with operative exploration.

Table 3: Results of duplex scan with operative exploration

\begin{tabular}{ccc}
\hline Operative exploration result & \multicolumn{2}{c}{ Duplex scan result } \\
\hline & Positive & Negative \\
Positive & 77 & 0 \\
Negative & 1 & 20 \\
\hline
\end{tabular}

Ages ranged from 13 to 62 years with a median age of 26 years. There were 86(87.7\%) Male and 12(12.2\%) female. Most injuries, 82(83.6\%) were sustained in road traffic accidents (RTA) (Table-4). Stabbings accounted for 6(6.1\%) injuries.Ten patients (10.2\%) suffered from fall injury. Eighty six patients(87.7\%) of blunt and 12(12.3\%) patients of penetrating injuries were observed. Table 5 showed the relation with and without associated fractures. 
D Chapagain et al. Management of acute peripheral arterial injury by using doppler ultrasonography..

Table 4: Mechanism of vascular injury

\begin{tabular}{lll}
\hline Mechanism & Frequency & Cases \\
\hline RTA(Pedestrian) & $10(10.2 \%)$ & \\
RTA(Motorcycle) & $34(34.6 \%)$ & \\
RTA(Four wheeler) & $24(24.4 \%)$ & \\
RTA(Bicycle) & $14(14.2 \%)$ & \\
Fall injury & $10(10.2 \%)$ & \\
Stabbing & $6(6.1 \%)$ & \\
\hline
\end{tabular}

Table 5: Associated fracture

\begin{tabular}{lccc}
\hline \multicolumn{1}{c}{ Associated with Fracture } & $\begin{array}{c}\text { Total blunt } \\
\text { injury }\end{array}$ & $\begin{array}{c}\text { Total } \\
\text { penetrating } \\
\text { injury }\end{array}$ \\
\hline $\begin{array}{l}\text { Penetrating } \\
\text { Blunt }\end{array}$ & $\begin{array}{l}3(3 . \%) \\
67(68.3 \%)\end{array}$ & \\
$\begin{array}{l}\text { Not associated with Fracture but having soft } \\
\text { tissue injury }\end{array}$ & $86(87.7 \%)$ & $12(12.3 \%)$ \\
$\begin{array}{l}\text { Penetrating } \\
\text { Blunt }\end{array}$ & $9(9.1 \%)$ & & \\
\hline
\end{tabular}

Table 6: Demographic profile

\begin{tabular}{lc}
\hline Male & $86(87.7 \%)$ \\
Female & $12(12.2 \%)$ \\
Range(age) & $13-62$ years \\
Mean age & 26 years \\
Total cases & 98 \\
Total injury & $77(78.54 \%)$ \\
\hline
\end{tabular}

Two patients (2.4\%) had neurological insufficiency in which one patient of subclavian artery injury had brachial plexus avulsion. Interposition graft using reversed long saphenous vein was the most common procedure performed in 44 (52.8\%) patients (Table7). Fasciotomy was performed during the primary operation in 6(7.2\%) patient but two(2.4\%) further patients required decompression for compartment
Table-7: Surgical procedure

\begin{tabular}{lcc}
\hline Surgical procedure & Frequency & Total \\
\hline Reversed vein graft & $44(52.8 \%)$ & \\
Primary repair & $8(9.6 \%)$ & \\
End to end anastomosis & $16(19.2 \%)$ & 77 \\
Patch repair & $5(6.4 \%)$ & \\
Radial / ulnar/tibial artery tie & $4(4.8 \%)$ & \\
\hline
\end{tabular}

syndrome. In two patients (2.4\%) grafts were thrombosed and undergone thrombectomy. Three patients(3.6\%) underwent post repair amputation. Twelve patients(14.4\%) had undergone repeated debridement. Six patients(7.2\%) had delayed wound healing. Eight patients(9.6\%) had malunion of fractured bone. We salvaged limb in $74(88.8 \%)$ out of 77 patients. 
Journal of College of Medical Sciences-Nepal, 2012, Vol-8, No-3

Table 8: Secondary procedure

\begin{tabular}{lcc}
\hline Procedure & Frequency & Total \\
\hline Thrombectomy & $2(2.4 \%)$ & \\
Fasciotomy & $6(7.2 \%)$ & \\
Skin graft & $12(14.4 \%)$ & 77 \\
Redo bypass & $1(1.2 \%)$ & \\
& & \\
\hline
\end{tabular}

Table 9: Complication

\begin{tabular}{lcc}
\hline Complication & Frequency & Total cases \\
\hline Compartment syndrome & $2(2.4 \%)$ & \\
Post repair amputation & $3(3.6 \%)$ & \\
delayed wound healing & $6(7.2 \%)$ & \\
Neurological defecit & $2(2.4 \%)$ & 77 \\
Malunion & $8(9.6 \%)$ & \\
Debridement & $12(14.4 \%)$ & \\
\hline
\end{tabular}

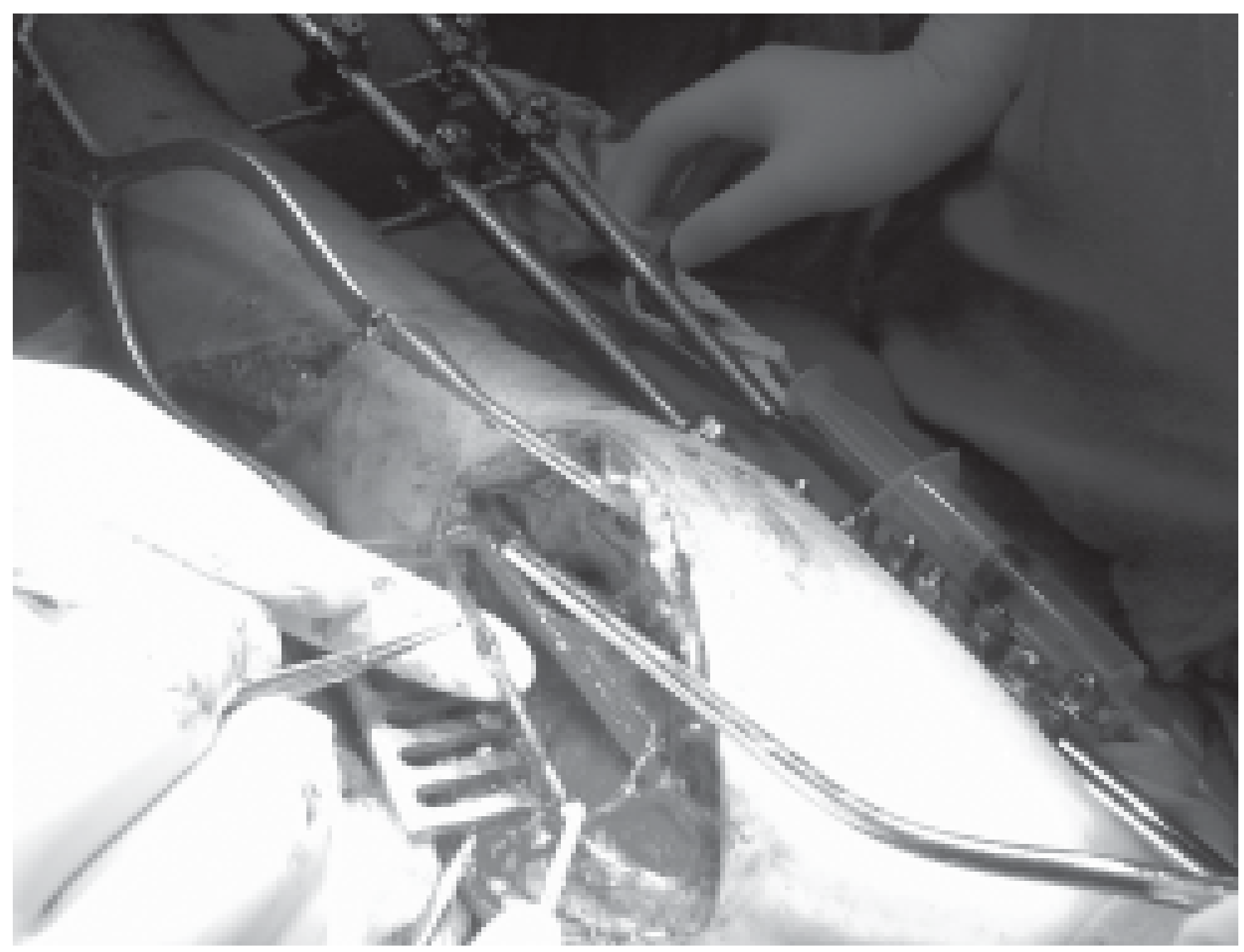

Exploration of femero-popliteal artery showing intimal injury 
D Chapagain et al. Management of acute peripheral arterial injury by using doppler ultrasonography.

\section{Discussion}

Early recognition of limb ischemia may allow prompt, effective therapy for peripheral arterial injuries. Ischemia may be difficult to recognize in patients with soft tissue or skeletal trauma, but the presence of distal pallor, coolness, paresis, cyanosis, anesthesia, poor capillary refill and disproportionate pain indicates significant arterial damage and necessitates surgical exploration.Clinical evaluation is the important factor to be considered for early recognition of the vascular trauma as mentioned by many authors. ${ }^{3,45}$

This can be supplemented by duplex scan in operation theatre. In this study there was no any delay in the exploration. The amputation rate was almost negligible after revascularisation procedure. The few amputation rate was not because of arterial insufficiency but because of extensive soft tissue injury and development of septic site. There can be some delay in the diagnosis of major arterial trauma by using arteriography which may be hazardous to the patient presenting in late stage in salvaging the limb. Lynch $\mathrm{K}$ et al showed that there could be a delay up to 2.4 hours while doing arteriography. ${ }^{6}$

In this study we used the duplex ultrasound extensively in perioperative period. Most of the patients had blunt injury and few patients had penetrating injury. Every patients having features of vascular compromise distal to the injury were taken to theatre immediately and duplex scan were done and operative exploration was done at the same time.This aggressive approach helped a lot to salvage the limb as described by Asworth EM.

In a animal model of arterial injury like occlusion, laceration, intimal flap and hematoma, duplex scanning and arteriography had similar accuracy; however, duplex scanning was significantly more sensitive than arteriography (90\% versus $80 \%$ ) in identifying arterial lacerations. $^{8}$

Duplex sonography is rapid, noninvasive, inexpensive, and portable device used extensively by vascular surgeon for the diagnosis of vascular injury having excellent sensitivity and specificity that was shown by this study. Many authors support this mode of diagnosis very much., ${ }^{9,10,11,12,13}$

Many blunt trauma cases were injured from vehicle accident. Younger male populations were involved. This is supported by some author. ${ }^{14}$

Most common pathology was thrombotic occlusion which were approved by exploration showing intimal injury. Other few patients had incomplete and complete transsection. Such types of injuries were most common in blunt trauma.Many of our patients were treated with reversed long sapheneous auto graft.Some of the patients underwent end to end anastomosis and few had undergone for patch repair.we ligated very few vessels like radial or tibial artery provided that the distal portion should have adequate perfusion. These types of management are commonly performed. ${ }^{15}$

Very few number of patients underwent intraoperative fasciotomy and post operative compartment syndrome were also less. So routine fasciotomy may not be necessary?.

We did not perform any primary amputation.It's rate is also very low. ${ }^{16}$

Some of the cases of soft tissue and bone releated complications like delayed wound healing, malunion 
Journal of College of Medical Sciences-Nepal, 2012, Vol-8, No-3

and repeated debridement were observed which were minor in nature.

\section{Conclusion}

The early recognition in the casualty plays a pivotal role in the promt diagnosis and initial management of vascular injuries. Understanding basic rules of diagnosis of vascular pathology in vascular trauma by using non invasive, cost effective, non time consuming method of duplex scan could salvage the limb to the maximum whose diagnostic accuracy is parallel to the operative finding and as good as to conventational arteriography or other methods of investigation.

\section{References}

1. Mani RL, Eisenberg RL, McDonald EJ, et al. Complications of catheter cerebral arteriography: analysis of 5000 procedures. I. Criteria and incidence. American Journal of Roentgenology, 1978, 131, 861-5.

2. Inui FK, Shannon J, Howard JM. Arterial injuries in the Korean conflict: Experiences with 111 consecutive injuries. Surgery 1955;37:850-7.

3. Menzoian 50, Doyle JE, Cantelmo NL, et al. A comprehensive approach to extremity vascular trauma. Arch Surg 1985;120: 801 -5.

4. Frykberg ER, Dennis JW, Bishop I, Laneve L, Alexander RH. The reliability of physical examination in the evaluation of penetrating extremity trauma for vascular injury: Results at one year. J Trauma 1991;31:502-11.

5. Goldman BS, Firor WB, Key JA. The Recognition and Management of Peripheral Arterial Injuries. Can Med Assoc J. 1965 May 29;92:1154-60

6. Lynch K, Johansen K. Can Doppler pressure measurement replace 'exclusion' arteriography in the diagnosis of occult extremity arterial trauma? Annals of Surgery, 1991, 241, 737-41.
7. Ashworth EM, Dalsing MC, Glover JL, et al. Lower extremity vascular trauma: A comprehensive, aggressive approach. J Trauma 1988;28:329-36.

8. Panetta TF, Hunt, JP, Buechter KJ, Et al. Duplex sonography versus arteriography in the diagnosis of arterial injury: an experimental study. Journal of Trauma, 1992, 33, 627-35.

9. Meissner M, Paun M, Johansen K. Duplex scanning for arterial trauma. Am J Surg 1991;161:552-5.

10. Greenwold D, Sessions EG, Haynes JL, et al. Duplex ultrasonography in vascular trauma. J Vasc Tech 1991;15:79-82.

11. Bynoe RP, Miles WS, Bell RM, et al. Noninvasive diagnosis of vascular trauma by duplex ultrasonography. J Vasc Surg 1991;14:346-52.

12. Schwartz MR, Weaver FA, Yellin AE, et al. The utility of color flow Doppler examination in penetrating extremity arterial trauma. Am Surg 1993;59:375-8.

13. Fry WR, Smith RS, Sayers DV, et al. The success of duplex ultrasonographic scanning in diagnosis of extremity vascular proximity trauma. Arch Surg 1993;128:1368.

14. Mattox KL, Feliciano DV, Burch J, et al. Five thousand seven hundred sixty cardiovascular injuries in 4459 patients: epidemiologic evolution 1958 to 1987. Ann Surg 1989;209:698-705.

15. Magee TR, Collin J, Hands LJ, et al. A Ten Year Audit of Surgery for Vascular Trauma in a British Teaching Hospital. Eur J Vasc Endovasc Surg 1996 12, $424-7$.

16. Gregory Modrall J, Weaver FA, Yellin AE. Diagnosis and management of penetrating vascular trauma and the injured extremity. Emergency Medicine Clinics $f$ North America. 1998;16;129-44. 